this fraction. Incorporation into glutamic acid was sufficient to account for the synthesis of at least $85 \%$ of the total mycelial $\alpha$-amino nitrogen content. The redistribution of label observed after the exhaustion of exogenous nitrogen confirmed previous non-isotopic evidence that a rapid turnover of insoluble nitrogen, involving breakdown to the amino acid level, occurred during nitrogen starvation. Extracellular organic nitrogen released after exhaustion of ammonia arose from the breakdown of insoluble mycelial material.

Thanks are due to Mr D. H. W. Scott for skilled technical assistance in the work described in this and the two preceding papers. I am also grateful to Mr R. G. Harrison for carrying out determinations with the mass spectrometer, and to Mr A. F. Henson for help in interpreting the isotopic data.

\title{
REFERENCES
}

Barratt, R. W. \& Strickland, W. N. (1963). Arch. Biochem. Biophys. 102, 66.

Bent, K. J. \& Morton, A. G. (1963). Trans. Brit. mycol. Soc. 46, 401.

Bent, K. J. \& Morton, A. G. (1964a). Biochem. J. 92, 260.

Bent, K. J. \& Morton, A. G. (1964b). Biochem. J. 92, 270.

Budd, K. \& Harley, J. L. (1962). New Phytol. 61, 138.

Bürk, R. R. \& Pateman, J. A. (1962). Nature, Lond., 196, 450.

Biochem. J. (1964), 92, 289

\section{Studies on the Nature of Polysomes}

\author{
By A. J. MUNRO, R. J. JACKSON AND A. KORNER \\ Department of Biochemistry, University of Cambridge
}

(Received 31 December 1963)

Polysomes are aggregates of ribosomes held together by RNA. These structures have been obtained from rat liver (Wettstein, Staehelin \& Noll, 1963; Noll, Staehelin \& Wettstein, 1963; Jackson, Munro \& Korner, 1963), reticulocytes (Marks, Burka \& Schlessinger, 1962; Warner, Knopf \& Rich, 1963; Gierer, 1963; Williamson \& Mathias, 1963), HeLa cells (Penman, Scherrer, Becker \& Darnell, 1963), ascites-tumour cells (White, Pedersen \& Hultin, 1963), rat heart (Earl \& Korner, 1963) and from bacteria (Spyrides \& Lipmann, 1962; Barondes \& Nirenberg, 1962; Staehelin, Brinton, Wettstein \& Noll, 1963a). Further, electron-micrographs have been published which indicate that aggregates of ribosomes can be attached to a thin strand which might be messenger RNA (Warner, Rich \& Hall, 1962; Williamson, Mathias, Huxley \& Page, 1963).

Polysomes are considered to be the functional
Conway, E. J. (1947). Microdiffusion Analysis and Volumetric Error, p. 95. London: Crosby and Lockwood.

Fincham, J. R. S. (1954). J. gen. Microbiol. 11, 236.

Folkes, B. F. (1959). Symp. Soc. exp. Biol. 13, 126.

. O. (1962). In Amino Acid Pools, p. 646. Ed. by Holden, J. T. Amsterdam: Elsevier Publishing Co.

\& Hanke, M. E. (1948). Practical Methods in Biochemistry, 5th ed., p. 383. Baltimore: Williams and Wilkins Co.

MacMillan, A. (1956). Physiol. Plant. 9, 533.

andelstam, J. (1963). Ann. N.Y. Acad. Sci. 102, art. 3, 621 .

Meyers, E. \& Knight, S. G. (1961). Mycologia, 53, 115.

Morton, A. G. (1961). Proc. Roy. Soc. B, 153, 548.

(1960). J. exp. Bot. 11, 116

Moses, V. (1959). J. gen. Microbiol. 20, 184

Shepherd, C. J. (1957). J. gen. Microbiol. 16, i.

Sobel, A. E., Hirschman, A. \& Besman, L. (1945). J. biol. Chem. 161, 99.

Sprinson, D. B. \& Rittenberg, D. (1949). J. biol. Chem. 180, 707.

Steward, F. C. \& Bidwell, R. G. S. (1962). In Amino Acid Pools, p. 667. Ed. by Holden, J. T. Amsterdam: Elsevier Publishing Co.

Yanagita, T. (1957). Arch. Mikrobiol. 26, 329.

Yemm, E. W. \& Cocking, E. C. (1955). Analyst, 80, 209.

Zalokar, M. (1959). Amer. J. Bot. 46, 602. units of protein biosynthesis by Wettstein et al. (1963) and Noll et al. (1963). They are called 'ergosomes' by these workers to indicate that these aggregates are the working particles and that the aggregate structure is necessary for protein synthesis in vivo and for amino acid incorporation in vitro. This viewpoint is supported by other workers (Goodman \& Rich, 1963) and models of the protein-biosynthetic mechanism have been propounded by them.

In this paper we first consider details of conditions necessary for optimum amino acid incorporation into protein with rat-liver polysomes, ribosomes and a total ribonucleoprotein particle preparation. We produce evidence that the strand to which ribosomes are attached in polysomes isolated from rat liver has some of the properties of messenger RNA. We question some details of the models of the protein-synthetic mechanism suggested by Wettstein 
et al. (1963), especially the conclusion that single ribosomes cannot incorporate amino acids into protein and that each ribosome of the polysome structure is active in incorporating amino acids into protein.

\section{METHODS}

Materials. Ribonuclease and the disodium salts of ATP and GTP were purchased from the Sigma Chemical Co. The trimethylammonium salt of phosphoenolpyruvate was prepared chemically and was a gift from Dr V. M. Clark. Phosphoenolpyruvate kinase was obtained from Boehringer und Soehne G.m.b.H., Mannheim, Germany. The commercial sucrose used was free of significant ribonuclease activity.

Polyuridylic acid was prepared from UDP by using the RNA-phosphorylase enzyme extracted from Micrococcus lysodeikticus and was a gift from $\mathrm{Dr} \mathrm{D}$. Kerridge. DL$\left[1-{ }^{14} \mathrm{C}\right]$ Leucine $(7 \mathrm{mc} / \mathrm{m}-\mathrm{mole}), \quad \mathrm{DL}-\left[1-{ }^{14} \mathrm{C}\right]$ phenylalanine $\left(10.8 \mathrm{mc} / \mathrm{m}\right.$-mole), ${ }^{14} \mathrm{C}$-labelled algal-protein hydrolysate $\left(145 \mu \mathrm{c} / \mathrm{mg}\right.$.) and $\left[{ }^{3} \mathrm{H}\right]$ orotic acid $(106 \mathrm{mc} / \mathrm{m}$-mole) were obtained from The Radiochemical Centre, Amersham, Bucks.

All solutions were made up in glass-distilled water and the $\mathrm{pH}$ was adjusted to $\mathbf{7 \cdot 6}$ (with tris for solutions that were acid).

Animals. Male and female albino rats of a strain bred in this Laboratory were used. They were starved overnight before use to deplete the liver of glycogen. Some rats were given actinomycin by intraperitoneal injection in propylene glycol and some were given $\left[{ }^{3} \mathrm{H}\right]$ orotic acid, dissolved in dilute $\mathrm{NaOH}$, by intraperitoneal injection or, on occasion, intravenously into the femoral vein while the rats were under light ether anaesthesia. Injection of ${ }^{14} \mathrm{C}$-labelled amino acids was intraportal (Sachs, 1958).

Preparation of cell sap. The rats were killed by decapitation, were bled and the liver was rapidly removed and cut finely in ice-cold $0.25 \mathrm{M}$-sucrose containing medium $\mathrm{M}$ $(0.02 \mathrm{M}$-tris buffer, $\mathrm{pH} 7 \cdot 6,10 \mathrm{~mm}$-magnesium acetate, $40 \mathrm{~mm}-\mathrm{NaCl}, 100 \mathrm{~mm}-\mathrm{KCl}$ and $6 \mathrm{~mm}$-mercaptoethanol). The liver was rinsed free of blood with the same medium and was weighed by displacement and homogenized in 3 vol. of a solution of fresh sucrose-medium $M$ by using three strokes of a loose-fitting ball plunger in a precision-bore glass homogenizer kept cold in an ice-bath. Mitochondria, nuclei and debris were removed by centrifugation for $10 \mathrm{~min}$. at $10000 \mathrm{~g}$ and at $0^{\circ}$ and the supernatant fluid was carefully removed and centrifuged for $2 \mathrm{hr}$. at $105000 \mathrm{~g}$ in the Spinco model $\mathrm{L}$ centrifuge. The cell sap was passed through a column (of at least ten times its own volume) of Sephadex G 25 equilibrated with medium $M$ to remove inhibitors from the cell sap (Mansbridge \& Korner, 1963).

Preparation of ribosomes, polysomes and total ribonucleoprotein particles. The $10000 \mathrm{~g}$ supernatant fluid, prepared as described above, was treated with one-ninth of its volume of an ice-cold $10 \%$ solution of sodium deoxycholate freshly dissolved in 0.05 $\mathrm{M}$-tris buffer, $\mathrm{pH} 8.2$, to solubilize the lipoprotein membranes of the endoplasmic reticulum (Palade \& Siekevitz, 1956). This deoxycholate-treated $10000 \mathrm{~g}$ supernatant (called S) served as starting material for the preparation of ribosomes, polysomes and total RNP* particles.

* Abbreviation: RNP, ribonucleoprotein.
Ribosomes were separated by centrifugation at $105000 \mathrm{~g}$ for $\mathbf{2} \mathrm{hr}$., the supernatant fluid was decanted, the inside of the tube and the surface of the pellet were rinsed with medium $\mathrm{M}$, the pellet was suspended by gentle homogenization in medium $M$ and the ribosomes were separated again by further centrifugation for $2 \mathrm{hr}$. at $105000 \mathrm{~g}$. The pellet was finally resuspended in medium $M$ by homogenization.

Polysomes were prepared essentially as described by Wettstein et al. (1963) by layering $6 \mathrm{ml}$. of S over $3 \mathrm{ml}$. of $0.5 \mathrm{M}$-sucrose containing medium $\mathrm{M}$, which was itself layered over $3 \mathrm{ml}$. of $2.0 \mathrm{M}$-sucrose containing medium $\mathrm{M}$, and centrifuging for $4 \mathrm{hr}$. at $105000 \mathrm{~g}$ and at $0^{\circ}$. The supernatant fluid was decanted and the pellet rinsed in medium $M$ and suspended by gentle agitation.

It was found that a preparation of the total RNP particles of $S$, cleaner than the ribosomes, could be obtained by layering $6 \mathrm{ml}$. of $\mathrm{S}$ over $6 \mathrm{ml}$. of $1 \mathrm{M}$-sucrose containing medium $M$ and centrifuging for $4 \mathrm{hr}$. at $105000 \mathrm{~g}$. The pellet could be resuspended in medium $M$ more easily than the ribosome pellet and was less contaminated by deoxycholate.

Incubation conditions. Samples of RNP particles and sap were shaken at $37^{\circ}$ for various times in a Dubnoff water bath. The standard incubation medium was medium $M$ containing $5 \mathrm{mM}$-ATP, $0.1 \mathrm{~mm}$-GTP and $0.5 \mu \mathrm{C}$ of radioactive amino acid. In some experiments different amounts of these components or of other materials were used and the specific details are given in the text. The incubation volume was $1 \mathrm{ml}$. Incubation was stopped by the addition of about $6 \mathrm{ml}$. of $0.5 \mathrm{~N}-\mathrm{HClO}_{4}$ containing unlabelled amino acid corresponding to the radioactive one used.

Preparation and counting of radioactive proteins. The precipitated proteins were washed three times with $0.5 \mathrm{~N}$ $\mathrm{HClO}_{4}$ containing unlabelled amino acid corresponding to the radioactive one used, to remove unincorporated radioactive amino acid. The pellet of protein was suspended each time by agitation with a Vortex Junior mixer model K-550J (Scientific Industries Inc., Springfield, Mass., U.S.A.). RNA was extracted by $0.5 \mathrm{~N}-\mathrm{HClO}_{4}$ at $100^{\circ}$ for $15 \mathrm{~min}$. This treatment also prevented loss of protein in the subsequent solvent-extraction steps. Lipids were removed by two washes with ethanol-ether- $\mathrm{CHCl}_{3}(2: 2: 1$, by vol.) mixture and the protein was dried by washing with ether.

The protein was dissolved in $0.4 \mathrm{ml}$. of $98 \%$ formic acid and the solution poured into the centre of weighed aluminium planchets $(3 \mathrm{~cm}$. diam.). An application of silicone high-vacuum grease around the lip edge of the planchet before weighing prevents the sample from flowing from the centre of the plate. The formic acid was evaporated off, the dried planchets were re-weighed and the radioactivity of the sample was estimated by counting with a NuclearChicago Corp. gas-flow counter. Sufficient counts were recorded to reduce the standard error to $3 \%$ or less and corrections for background counts and self-absorption were made. Results are reported as specific activity of the protein plated or, where different RNP particles were compared, as counts $/ \mathrm{min}$. incorporated into protein $/ \mathrm{mg}$. of particle RNA incubated.

Determination of $R N A$. Triplicate samples of particle suspensions were used for RNA determination by the modification proposed by Fleck \& Munro (1962) of the method of Scott, Fraccastoro \& Taft (1956). Acid-soluble nucleotides were removed by washing with cold $0.5 \mathrm{~N}-\mathrm{HClO}_{4}$ and the 
precipitate was hydrolysed for $1 \mathrm{hr}$. at $37^{\circ}$ in $0.3 \mathrm{~N}-\mathrm{NaOH}$. The hydrolysate were acidified to $\mathrm{pH} 1$ with $6 \mathrm{~N}-\mathrm{HCl}$, and the absorption at $260 \mathrm{~m} \mu$ of the acid-soluble fraction was measured. The extinction coefficient used was $34 \cdot 2 / \mathrm{mg} . / \mathrm{ml}$./ cm. (Scott et al. 1956).

It was found necessary to take the sample for RNA estimation at the time when samples were taken for incubation since precipitation of the RNP material occurred on storage at $0^{\circ}$ or $-15^{\circ}$ and this interfered with accurate sampling. Losses of material during handling occurred and were particularly serious if the sample contained less than $0.2 \mathrm{mg}$. of RNA. Large samples were therefore used for the estimations, or, where this was not possible, a known amount of cell sap (about $1 \mathrm{mg}$. of protein) was added as carrier and triplicate samples of it were analysed by the same method to determine the blank value. With carrier protein, it was possible to obtain accurate RNA estimation of samples containing as little as $0.005 \mathrm{mg}$. of RNA.

Determination of protein. Triplicate samples of S, RNP particle suspensions and cell sap were used for protein estimation by the method of Lowry, Rosebrough, Farr \& Randall (1951), with bovine serum albumin as a standard.

Analysis of RNP particles by sucrose-gradient centrifugation. Sucrose gradients were prepared in centrifuge tubes for the SW 25 and the SW 39 rotors of the Spinco model $L$ centrifuge, a mixing device similar to that described by Britten \& Roberts (1960) being used. Both linear and exponential gradients were employed and various ranges of sucrose concentrations were used. On occasion a 'cushion' was employed by putting $0.5 \mathrm{ml}$. of $2 \mathrm{M}$-sucrose at the bottom of the tube. The sucrose for the gradients contained buffer and salts and details of these are given where appropriate in the text. It was noted that mercaptoethanol in the presence of magnesium interfered with the extinction at $260 \mathrm{~m} \mu$, so mercaptoethanol was omitted from medium $\mathbf{M}$ when this was used in sucrose gradients. Small volumes of the material to be analysed ( $\mathrm{S}$ or particle preparations) were layered on to the gradient and the tubes spun in the precooled rotor for various periods.

After centrifugation the tube was held vertically in a clamp and stoppered with a rubber bung carrying a tube to a simple device capable of applying a slight negative pressure to the gradient. A hole was made in the bottom of the tube with a no. 1 hypodermic needle with a specially sharpened and shortened point. The needle was mounted in a small piece of rubber liberally coated with silicone grease to avoid leakage of material around the needle. During puncturing a wire was kept in the needle to prevent the small piece removed from the tube blocking the needle. The part of the needle which normally fits a hypodermic syringe had been replaced by a brass cup which provided a surface on which drops of equal size formed. The drops were counted into tubes, the material was diluted with cold glass-distilled water and its extinction at 260 and $320 \mathrm{~m} \mu$ determined. The reading obtained with samples of different concentrations of sucrose-salts at $260 \mathrm{~m} \mu$ was recorded and these blank readings were subtracted from the experimental readings.

If the samples contained radioactive RNA, each sample, after measurement of its extinction, was precipitated with ice-cold $0.5 \mathrm{~N}-\mathrm{HClO}_{4}$ and the precipitate collected by filtration on Oxoid membranes, washed with cold $0.5 \mathrm{~N}-\mathrm{HClO}_{4}$ and with $2 \%(v / v)$ acetic acid, dried at $65^{\circ}$ for $1 \mathrm{hr}$. and placed in a vial for counting in a Packard scintillation counter, using as scintillator toluene containing 2,5- diphenyloxazole (3.5 g./1.) and 1,4-bis-(5-phenyloxazol-2yl)benzene (50 mg./l.).

If the samples from the gradient contained radioactive protein, they were precipitated with $0.5 \mathrm{~N}-\mathrm{HClO}_{4}$ containing unlabelled amino acid corresponding to the radioactive one used, heated to $95^{\circ}$ for $15 \mathrm{~min}$. and filtered on to membrane filters, washed twice with ethanol-ether $(1: 1, v / v)$ and once with ether. They were either stuck to a cardboard disk and their radioactivities assessed by counting with a Nuclear-Chicago Corp. gas-flow counter, or the dry membranes were placed in a vial for counting in a Packard scintillation counter.

We found that use of the extinction at $260 \mathrm{~m} \mu$ as a quantitative measure of the nucleic acid content of RNP particles in samples after sucrose-gradient centrifugation was subject to considerable error because of the presence of non-RNP proteins, especially ferritin, which absorbs at $260 \mathrm{~m} \mu$. We have used a calculated correction factor (see Jackson et al. 1963, and unpublished work), subtracting $1.51 \times$ reading at $320 \mathrm{~m} \mu$ from the reading at $260 \mathrm{~m} \mu$ to allow for this error. A considerable alteration in the sucrose-gradient profiles of liver RNP particles results, especially in the region of monomeric ribosomes that run near the ferritin band which has a sedimentation coefficient of $65 \mathrm{~s}$.

Extraction and examination of radioactive $R N A$. Since potassium precipitated dodecyl sulphate, tissue fractions used for RNA preparation were suspended in $0.02 \mathrm{M}$-tris buffer, $\mathrm{pH} 7 \cdot 6$, containing sodium dodecyl sulphate rather than in medium M. RNA was extracted from ribosomes and microsomes suspended in $0.02 \mathrm{M}$-tris buffer, $\mathrm{pH} 7 \cdot 6$, containing $1 \%$ sodium dodecyl sulphate, with freshly redistilled phenol in the presence of bentonite (Hall \& Doty, 1959). If nuclei were present in the tissue the dodecyl sulphate concentration was kept below $0 \cdot 1 \%$ to stop the extraction of DNA (Dingman \& Sporn, 1962). After centrifugation the aqueous layer was removed, the phenol layer washed with buffer and the combined washings were treated again with phenol. The aqueous layer was made $2 \%$ with respect to sodium acetate (at $\mathrm{pH} 5 \cdot 2$ ) and $2 \frac{1}{2}$ vol. of ethanol was added to precipitate the RNA, which was washed repeatedly with ethanol to remove phenol, dissolved in $0.01 \mathrm{~m}$-acetate buffer, $\mathrm{pH} 5 \cdot 2$, containing $0 \cdot 1 \mathrm{M}-\mathrm{NaCl}$, and reprecipitated with ethanol. Finally the RNA was dissolved in the acetate buffer and samples were taken for radioactive counting by filtering and washing on to membrane filters, for measurement of extinction at $260 \mathrm{~m} \mu$ and for analysis by sucrosegradient centrifugation with $20-5 \%$ linear gradients.

\section{RESULTS}

Conditions for optimum incorporation with three types of RNP particles. For part of our argument it was necessary to compare the amino acid-incorporating ability of different types of RNP particles. To do this the incubation conditions for each must be those which are likely to result in optimum amino acid incorporation and where factors other than the incorporating ability of the particles are not limiting. Polysomes are very readily broken down to monomeric ribosomes (Wettstein et al. 1963) so that the vigorous pro- 
cedures necessary to suspend ribosome pellets and the need to wash them to remove deoxycholate (Korner, 1961) would be expected to break any polysome aggregates present to monomeric ribosomes (Warner et al. 1963). To compare the properties of polysomes with those of the total RNP particles of the $10000 \mathrm{~g}$ supernatant treated with sodium deoxycholate we have used preparations of total RNP particles of $S$ made by layering $S$ over $1 \mathrm{M}$-sucrose as described in the Methods section. The pellet of these particles is yellow rather than red, probably because it is less contaminated than ribosomes by ferritin and other proteins and it is also less contaminated by deoxycholate. It was therefore not necessary to wash the pellet by resuspension and recentrifugation and it proved possible to suspend it by much gentler treatment than that necessary for ribosomes. At the same time it is a preparation of essentially all the RNP particles present in $\mathrm{S}$ and is not a selection of the heavier particles as is a polysome preparation. Here, then, is a preparation which can be compared more fairly with polysomes than can ribosomes.

Table 1 shows typical values of RNA:protein ratio of ribosomes, polysomes and total RNP particles and summarizes the conditions for optimum amino acid incorporation.

Like ribosomes (Korner, 1961), polysomes do not require the addition of a ATP-generating system for optimum amino acid incorporation. The results show that, provided that $5 \mathrm{~mm}-\mathrm{ATP}$ and $10 \mathrm{~mm}$ $\mathrm{Mg}^{2+}$ ions are present, the addition of phosphoenol- pyruvate and phosphoenolpyruvate kinase does not increase the amino acid incorporation into protein. Higher concentrations of ATP can cause inhibition of incorporation unless extra $\mathrm{Mg}^{2+}$ ions are also added but little increased incorporation was obtained when amounts of ATP greater than $5 \mathrm{~mm}$ were used, even with extra $\mathrm{Mg}^{2+}$ ions.

The extent of stimulation by GTP varies from experiment to experiment even though the sap had been passed through a column of Sephadex and had presumably been freed from GTP. It seems probable that variable amounts of GTP may be associated with the particles or remain in the sap even after treatment with Sephadex.

In agreement with the findings of Wettstein et al. (1963), we found that addition of small amounts of an amino acid mixture, lacking the radioactive one, enhanced amino acid incorporation. Stimulation was seen only when the amino acids in the cell sap had been removed by treatment with Sephadex. Here again the extent of stimulation varied from experiment to experiment. The inhibitory effect of high concentration of amino acid mixture on leucine incorporation into protein with ribosomes (Kirsch, Siekevitz \& Palade, 1960; Tissières, Schlessinger \& Gros, 1960; Korner, 1961), and now noted with polysomes (Table 1 ), is at least partially explicable by the presence of small traces of leucine in the amino acid mixture. Traces were detected by paper electrophoresis of the amino acids with a fluorescent end-group reagent (Gray \& Hartley, $1963)$.

Table 1. Properties of ribosomes, total ribonucleoprotein particles and polysomes and conditions for their optimum incorporation of amino acid

Details of the complete incubation mixture are given in the Methods section.

1 Colour of pellet

2 Typical RNA/protein ratio

3 Optimum concentrations ( $\mathrm{mM})$ of ions

$$
\begin{aligned}
& { }^{*} \mathrm{Na}^{+} \text {(with } 100 \mathrm{~mm}-\mathrm{K}^{+} \text {) } \\
& \mathrm{K}^{+} \text {(with } 40 \mathrm{mM}-\mathrm{Na}^{+} \text {) } \\
& \mathrm{Mg}^{2+}
\end{aligned}
$$

Total $\mathrm{Na}^{+}+\mathrm{K}^{+}$should be about $140 \mathrm{~mm}$ : distribution between them is less important.

4 Percentage inhibition when the following were omitted from the incubation mixture:

Particles
Cell sap
ATP
GTP

5 (a) Percentage rise on adding $0 \cdot 1 \mathrm{mg}$. of amino acid mixture

(b) Percentage rise on adding $1.0 \mathrm{mg}$. of amino acid mixture

6 Percentage rise on addition of phosphoenolpyruvate and its kinase

7 Percentage rise with an extra 5 mM-ATP +5 mM-magnesium acetate

8 Relative sp. activity/mg. of particle RNA incubated (each under optimum conditions; total particles taken as 100)
Ribosomes Total particles Reddish brown Reddish yellow $0 \cdot 7$ 0.9

Polysomes Colourless $1 \cdot 2$

$\begin{array}{rrr}40 & - & 20 \\ 100 & - & 100 \\ 10 & 10 & 10\end{array}$

20
99 95 98 40 38

(61\% if ribosomes also treated with Sephadex)

-20
8
9
83

$100 \quad 124$ 
The effect of adding different concentrations of cell sap, before and after passing it through a Sephadex column, on amino acid incorporation into polysomes is shown in Fig. 1. The treatment with Sephadex stimulated incorporation and stops the inhibition of incorporation found with high concentrations of untreated cell sap. A 25:1 protein ratio, cell sap (treated with Sephadex) to particles, seemed to be sufficient for maximal amino acid incorporation. Clearly, when one wishes to compare the ability of different types of RNP particles to incorporate amino acid into protein it is essential to pass the cell sap through Sephadex to remove inhibitors and to use such a quantity of it that (cellsap protein)/(RNP-particle protein) is greater than 25 , so that cell sap is not limiting.

The last line of Table 1 compares the efficiency of amino acid incorporation of ribosomes, polysomes and total RNP particles each under the optimum conditions. The results are presented as counts/ min. incorporated into protein/mg. of particle RNA incubated as a percentage of the value for the total RNP particles and it can be seen that polysomes are the most efficient but that good incorporation was obtained with ribosomes and total RNP particles.

Messenger nature of the RNA strand in polysomes. It has been assumed that the strand which can be seen in electron-micrographs prepared from reticulocyte cells and which holds the ribosomes together is RNA because polysomes can be degraded to single ribosomes by treatment with small amounts of ribonuclease at low temperature (Arnstein, 1961; Wettstein et al. 1963). That the connecting RNA is messenger RNA has not been so clearly established but has been assumed by many workers (Goodman \& Rich, 1963; Wettstein et al. 1963).

Polysomes were prepared from rat liver $30 \mathrm{~min}$. after injection of $\left[{ }^{3} \mathrm{H}\right]$ orotic acid and analysed by sucrose-gradient centrifugation (Fig. 2). Radioactive RNA was associated with the polysomes and most of the radioactivity became acid-soluble if the preparation had been treated with $1 \mu \mathrm{g}$. of ribonuclease $/ \mathrm{ml}$. for $5 \mathrm{~min}$. at room temperature. This procedure converted polysomes into ribosomes but did not render the structural RNA of the ribosomes acid-soluble.

Fig. 3 shows an assay, by sucrose-gradient centrifugation, of the proportion of polysomes in liver $10000 \mathrm{~g}$ deoxycholate-treated supernatant of normal and actinomycin-treated rats. It is clear that actinomycin treatment has resulted in a drastic lowering of the number of polysomes present.

Amino acid incorporation by single ribosomes. Fig. 4 shows the typical result of an experiment in which the RNP particles were separated into their different sizes by sucrose-gradient centrifugation, and the ability of each fraction to incorporate amino acids into protein was studied. It can be seen that the specific activity/mg. of particle RNA incubated is fairly constant from the region of the gradient where heavy particles are found to the region where aggregates of about three ribosomes

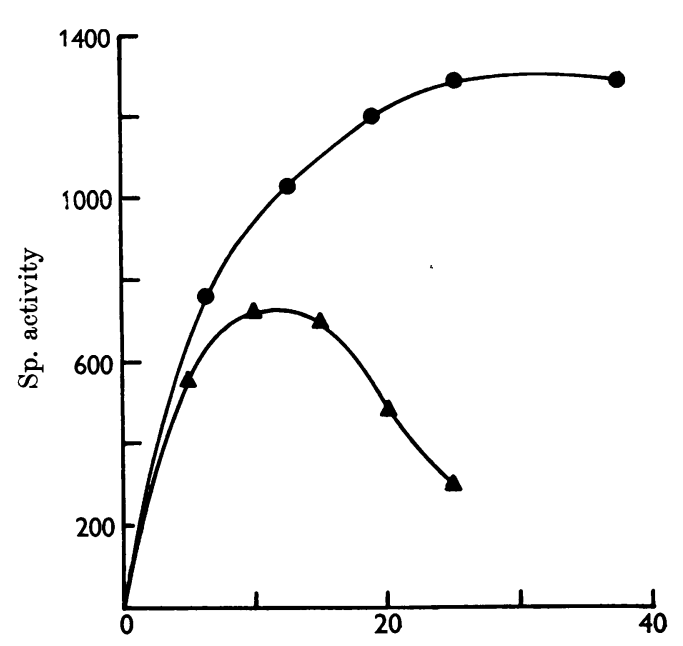

Cell-sap protein (mg./mg. of ribosomal protein)

Fig. 1. Effect of cell-sap concentrations on amino acid incorporation into protein in vitro. 0 , Sap treated with Sephadex; $\Delta$, untreated sap. Details of the incubation mixture and Sephadex treatment are given in the Methods section.

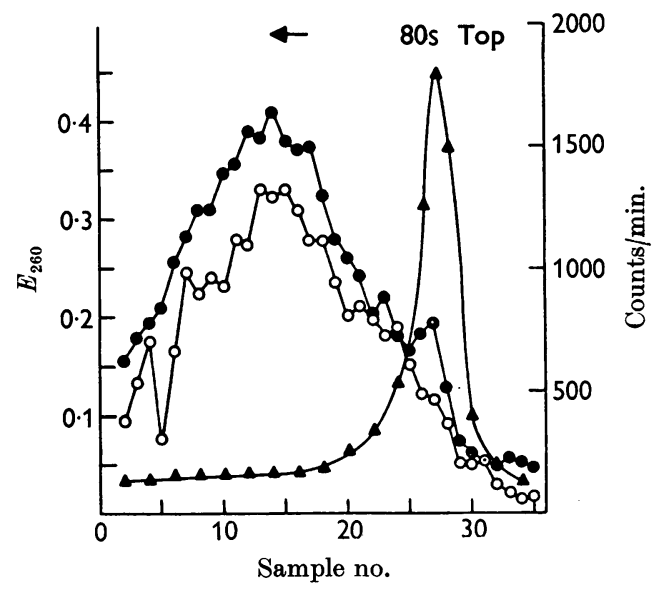

Fig. 2. Sucrose-density-gradient analysis of rat-liver polysomes prepared $30 \mathrm{~min}$. after injection of $1 \mathrm{mc}$ of $\left[{ }^{3} \mathrm{H}\right]$ orotic acid into the rat.,$E_{260} ; 0$, counts/min.; $\Delta, E_{260}$ of polysomes treated with $1 \mu \mathrm{g}$. of ribonuclease before centrifugation. Direction of centrifugal force is shown by an arrow and the top of the gradient is indicated. A 30-10\% sucrose gradient containing medium $\mathbf{M}$ (without mercaptoethanol: see Methods section) was used. Centrifugation was at $22500 \mathrm{rev} . / \mathrm{min}$. for $2 \mathrm{hr}$. 
sediment. Aggregates smaller than this show a lower activity but amino acid incorporation has occurred in the monomeric ribosomes. The fall in specific activity with smaller aggregates may be attributed to the presence of inactive monomeric or dimeric ribosomes.

Effect of magnesium concentration on size and activity of polysomes. Polysomes, prepared in the normal way in a magnesium-containing buffer, were suspended in the same buffer but with differing final concentrations of $\mathrm{Mg}^{2+}$ ions (varying from 0 to $10 \mathrm{~mm}$ ). The buffer contained the usual concentrations of the other ions (which can be expected to influence particle size; Hamilton \& Petermann,

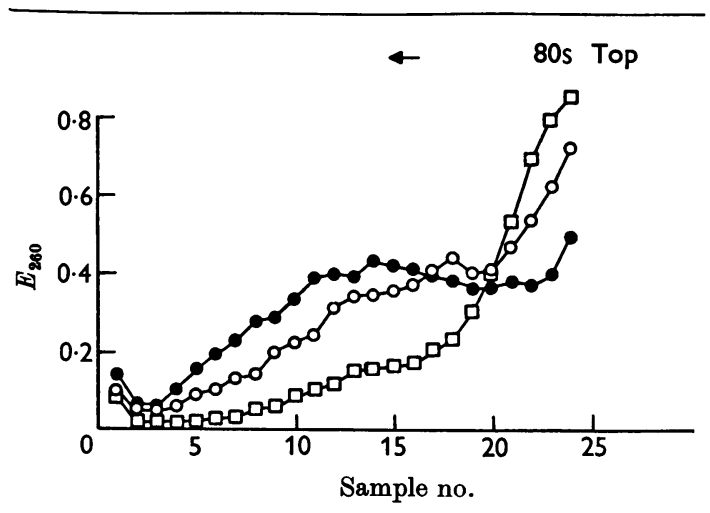

Fig. 3. Sucrose-density-gradient analysis of $10000 \mathrm{~g}$ deoxycholate-treated supernatant of liver homogenates of rats given $500 \mu \mathrm{g}$. of actinomycin. O, No actinomycin; $\mathrm{O}$, actinomycin $7 \mathrm{hr}$. previously; $\square$, actinomycin $12 \mathrm{hr}$. previously. A 30-15\% sucrose gradient containing medium M (without mercaptoethanol) was used. Centrifugation was at $37000 \mathrm{rev} . / \mathrm{min}$. for $40 \mathrm{~min}$.

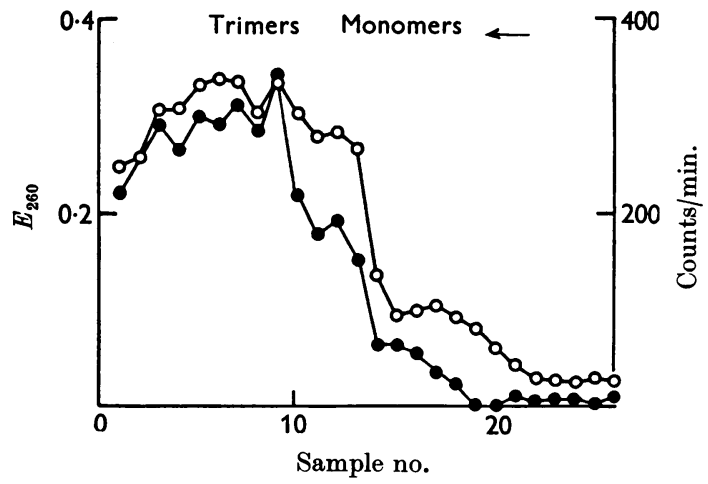

Fig. 4. Sucrose-density-gradient analysis of a ribosome preparation of rat liver. $\bigcirc, E_{260} ; O$, counts $/ \mathrm{min} . / \mathrm{mg}$. of particle RNA after incorporation of $\mathrm{DL}-\left[1-{ }^{14} \mathrm{C}\right]$ leucine into protein in vitro with the separated RNP fractions. Details of gradient are as given for Fig. 2. Centrifugation time, $4 \mathrm{hr}$.
1959). The particles were centrifuged through $0.5 \mathrm{M}$ sucrose containing buffer with the same $\mathrm{Mg}^{2+}$ ion concentration as was used to suspend them and each pellet was then analysed by sucrose-gradient centrifugation. The sucrose of the gradient contained the usual buffer save that the $\mathbf{M g}^{2+}$ ion concentration was that used to prepare each particular pellet.

It can be seen from Fig. 5 that particles which were prepared and analysed in the highest $\mathrm{Mg}^{2+}$ ion concentration show a typical polysome-distribution pattern with few particles in the monomeric ribosome region. Lowering the $\mathbf{M g}^{2+}$ ion concentration to $1 \mathrm{~mm}$ caused little change in the distribution pattern although slightly more particles appeared in the monomeric region. When, however, the $\mathrm{Mg}^{2+}$ ion concentration was lowered to $0.1 \mathrm{~mm}$ a large change was observed; less polysomes were present but many more monomeric and dimeric ribosomes appeared. When the $\mathbf{M g}^{2+}$ ion concentration was lowered still further, to 0.01 or $0.001 \mathrm{mM}$, or when the particles were spun through a medium containing no magnesium, further breakdown of the polysomes occurred. It was noticed that the differences observed between the three lowest $\mathrm{Mg}^{2+}$ ion concentrations are minimal, and, further, that some polysomes exist even at very low $\mathrm{Mg}^{2+}$ ion concentration.

The particle material prepared in this fashion was used in incorporation experiments under the usual conditions in vitro and the specific activities

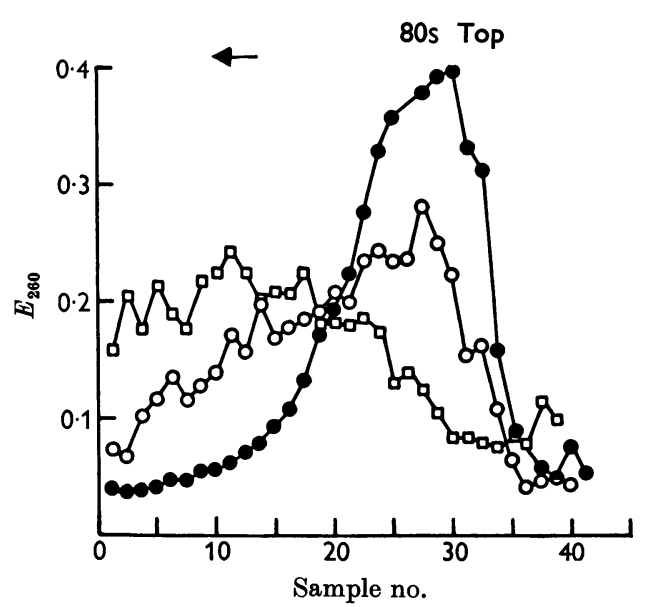

Fig. 5. Sucrose-density-gradient analysis of polysomes of rat liver washed and analysed in sucrose-medium $M$ containing various concentrations of magnesium acetate: , $0.001 \mathrm{~mm}$; $\bigcirc, 0.1 \mathrm{~mm}$; $\square, 10 \mathrm{~mm}$. (Results obtained with other magnesium concentrations have been omitted from the Figure for clarity.) A 30-10\% sucrose gradient containing medium $\mathrm{M}$ (without mercaptoethanol) and containing the magnesium concentrations detailed above was used. Centrifugation was at $37000 \mathrm{rev} . / \mathrm{min}$. for $40 \mathrm{~min}$. 
obtained are shown in Table 2. It can be seen that little difference in incorporating ability was obtained no matter what proportions of monomeric and polymeric ribosomes were present in the system.

The possibility that the monomeric ribosomes reaggregated into polysomes when magnesium was added to them before incubation and that these reaggregated structures were responsible for the incorporation obtained can be discounted by the data presented in Fig. 6. Particles made in the absence of magnesium were analysed on sucrose gradients in the absence or presence of $5 \mathrm{~mm}$ magnesium acetate. The maximum extent of reaggregation can be seen to be small when compared with the large breakdown in the absence of magnesium noted in Fig. 5.

Several explanations of this result can be offered (see Discussion section): one, which is disproved below, is that messenger RNA is split into small pieces (to each of which is attached an active ribo-

Table 2. Amino acid incorporation into protein with polysomes prepared and centrifuged through gradients containing different concentrations of magnesium acetate

The material is the same as that of Fig. 5 .

$\begin{array}{cc}\begin{array}{c}\text { Concn. of } \\ \text { magnesium in } \\ \text { preparation } \\ \text { (mM) }\end{array} & \begin{array}{c}\text { Radioactivity } \\ \text { (counts/min./mg. } \\ \text { of protein/mg. of } \\ \text { particle RNA } \\ \text { incubated) }\end{array} \\ 0 & 2400 \\ 0.001 & 2140 \\ 0 \cdot 01 & 2360 \\ 0 \cdot 1 & 2000 \\ 1 \cdot 0 & 2360 \\ 10 \cdot 0 & 2680\end{array}$

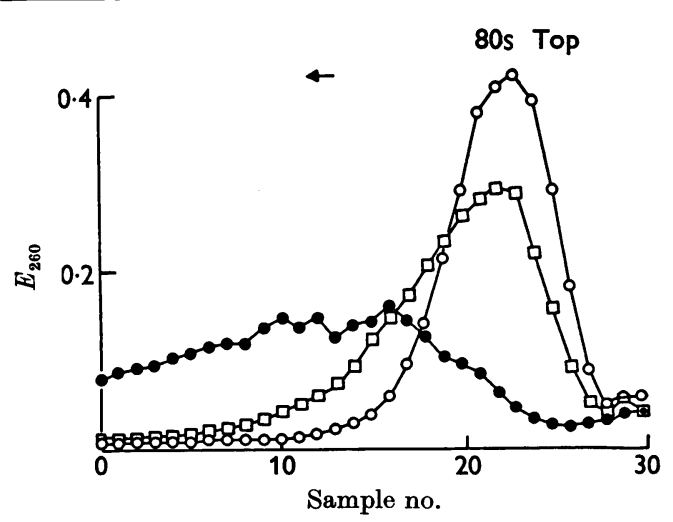

Fig. 6. Sucrose-density-gradient analysis of polysomes, made in the absence of magnesium and analysed in the absence (O) or presence $(\square)$ of $\mathbf{M g}^{2+}$ ions. O, Normally prepared polysomes. Details of the gradient are as given for Fig. 5. some), by lowering the $\mathrm{Mg}^{2+}$ ion concentration, which might activate latent ribonuclease (Elson \& Tal, 1959).

RNA was extracted from RNP particles, prepared in the absence or the presence of $\mathbf{M g}^{2+}$ ions, from rats given a $30 \mathrm{~min}$. 'pulse' of $\left[{ }^{3} \mathrm{H}\right]$ orotic acid (Fig. 7). The RNA was analysed on sucrose gradient in acetate buffer and little difference between the two preparations was seen either in the pattern of extinction at $260 \mathrm{~m} \mu$ or in specific activity. This result indicates that no substantial breakdown of the structural RNA had occurred on preparing the particles in the absence of magnesium.

Fig. 8 shows the results of an experiment in which rats were injected with ${ }^{14} \mathrm{C}$-labelled algal-protein hydrolysate and $2 \mathrm{~min}$. later the liver was removed and used for the preparation of RNP particles, which were then separated on sucrose gradient in the presence or absence of $\mathrm{Mg}^{2+}$ ions. When magnesium was present in the preparative media the specific activities fell from the heaviest particles to the lighter ones. In the absence of magnesium from the preparative media, the specific activity was higher in the heavier region and the fall was much steeper than in the previous case.

Rats injected with $\left[{ }^{3} \mathrm{H}\right]$ orotic acid were killed $30 \mathrm{~min}$. later and total RNP particles prepared from their liver. Most of the radioactivity of the preparation is expected to be associated with messenger RNA (Munro \& Korner, 1962). The particles were then analysed by sucrose-gradient centrifugation in the presence or the absence of magnesium. The result is shown in Fig. 9, which shows a difference between the slopes of the two plots of specific activity.

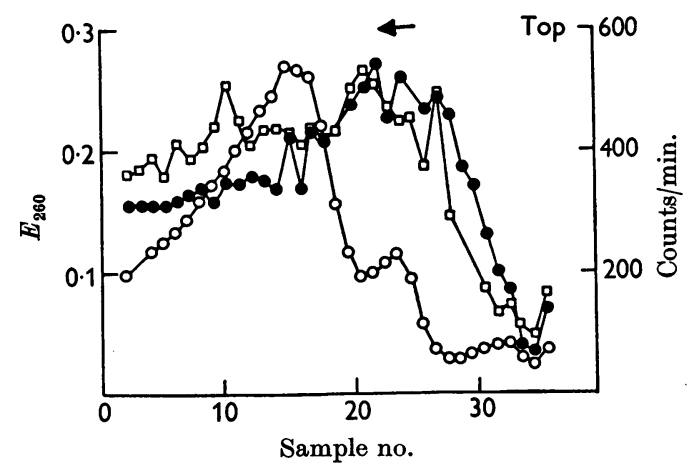

Fig. 7. Sucrose-density-gradient analysis of RNA extracted from RNP particles of liver of a rat given $1 \mathrm{mo}$ of $\left[{ }^{3} \mathrm{H}\right]$ orotic acid 30 min. previously., RNA (counts/min.) prepared in the absence of magnesium; $\square$, RNA (counts/min.) prepared in the presence of magnesium; $O, E$ of both RNA samples (which were identical). A 20-5\% sucrose gradient containing $0.01 \mathrm{M}$-acetic acid and $0.1 \mathrm{M}-\mathrm{NaCl}$ at $\mathrm{pH} 5.2 \mathrm{was}$ used. Centrifugation was at $37000 \mathrm{rev} . / \mathrm{min}$. for $4 \mathrm{hr}$. 


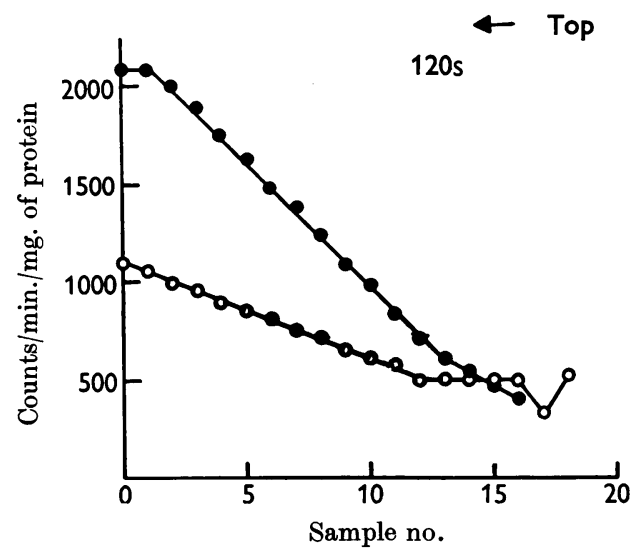

Fig. 8. Sucrose-density-gradient analysis of RNP particles of liver of rat given ${ }^{14} \mathrm{C}$-labelled algal-protein hydrolysate 2 min. previously. O, Separated on the gradient with magnesium; 0 , separated on the gradient in the absence of magnesium. Details of the gradient are as given for Fig. 2.

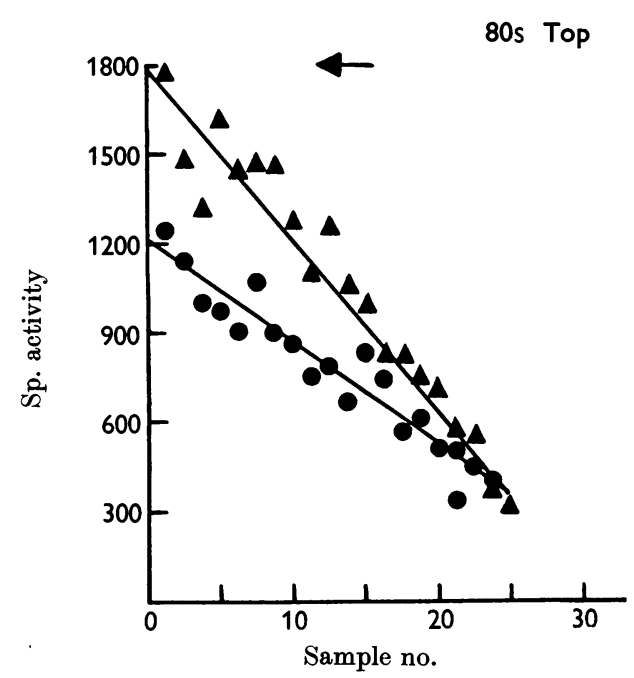

Fig. 9. Sucrose-density-gradient analysis of RNP particles of liver of rat given $\left[{ }^{3} \mathrm{H}\right]$ orotic acid $30 \mathrm{~min}$. previously. - Separated on the gradient with magnesium; $\boldsymbol{\Delta}$, separated on the gradient in the absence of magnesium. Details of the gradient are as given for Fig. 2.

Table 3 shows the result of typical experiments when a comparison of the amino acid incorporation into protein in vitro of polysomes prepared in the presence or absence of $\mathbf{M g}^{2+}$ ions was made. As can be seen, preparation of particles in the absence of $\mathrm{Mg}^{2+}$ ions did not result in a drastic lowering of amino acid incorporation but often resulted in enhanced incorporation.
Table 3. Amino acid incorporation into protein with polysomes made in the presence or the absence of magnesium

$\begin{array}{ccc}\text { Expt. } & \text { Radioactivity } \\ \text { no. } & \text { Magnesium } & \begin{array}{c}\text { Rarticle RNA } \\ \text { of protein/mg. of } \\ \text { incubated) }\end{array} \\ 1 & \text { Present } & 2040 \\ & \text { Absent } & 2270 \\ 2 & \text { Present } & 1960 \\ & \text { Absent } & 1790 \\ 3 & \text { Present } & 2500 \\ & \text { Absent } & 2650\end{array}$

\section{DISCUSSION}

Wettstein et al. (1963) (cf. Goodman \& Rich, 1963) have proposed a model of the proteinbiosynthetic mechanism in which a group of ribosomes are attached to messenger RNA forming a polysome and each ribosome is thought to roll along the messenger RNA synthesizing protein as it goes in accordance with the information coded in the messenger RNA. When the ribosome reaches the end of the messenger RNA it detaches itself and other ribosomes are envisaged as being capable of attaching themselves to the 'starter' end of the messenger RNA. The basic features of this scheme are: (1) that the ribosomes in the polysome structure are attached to a strand which is messenger RNA; (2) that a polysome structure is essential, that is to say that single ribosomes are incapable of amino acid incorporation in vitro or of protein biosynthesis in vivo (Noll et al. 1963) [Originally Wettstein et al. (1963) suggested that an ergosome (polysome) consisted of five ribosomes attached to one messenger RNA but this view seems to have been modified (Noll et al. 1963) into the idea that 'polysome' is a generic term for a number of ribosomes, greater than one, attached to a messenger RNA strand. The number attached depends on the length of the messenger RNA which in turn is a function of the length of the protein to be synthesized]; (3) that each ribosome of the polysome structure is synthesizing protein; (4) that the ribosomes roll along the messenger RNA during protein biosynthesis.

The results reported in this paper lend support to some of the features of the model proposed by Wettstein et al. (1963) but some of the results suggest that explanations other than those put forward by Wettstein et al. (1963) cannot be discounted.

We agree that the strand to which, ribosomes are attached in the polysome structure is probably messenger RNA. We have shown (Munro \& Korner, 1962), in contrast with Hiatt (1962), that orotic 
acid injected into rats is rapidly incorporated into a minor component of cytoplasmic RNA of sedimentation coefficient between $6 \mathrm{~s}$ and $18 \mathrm{~s}$, with a base composition unlike that of the ribosomal structural RNA and with some of the characteristics of messenger RNA. That some of this rapidly labelled RNA accompanies the polysome fraction (Fig. 2) and becomes acid-soluble when the polysomes are changed to monomeric ribosomes by treatment with amounts of ribonuclease small enough not to hydrolyse the ribosomal structural RNA suggests strongly that the strand on which the ribosomes are strung together is indeed messenger RNA. Support for this conclusion is provided by treatment of the rat with actinomycin (Fig. 3), which resulted in a drastic lowering of the proportion of polysomes in the $10000 \mathrm{~g}$ deoxycholatetreated supernatant. This result confirms that of Staehelin, Wettstein \& Noll (1963b). This decrease in the number of polysomes in rat liver accompanies the known inhibition of RNA synthesis (Merrits, 1963 ; Franklin, 1963) and is also accompanied by a fall in protein-synthetic ability of the system in vitro (Korner \& Munro, 1963). These two pieces of evidence, taken together, support the idea that the connecting link in the polysome is messenger RNA.

In our view RNP particles can be active in amino acid incorporation into protein if one (or more) ribosomes is properly attached to a messenger RNA and has associated with it the enzymes and other factors needed for peptide-bond formation between the activated amino acids attached to their specific s-RNA molecules. We do not believe that a polysome structure, that is a messenger RNA with several ribosomes attached to it, is essential for amino acid incorporation into protein in vitro (Figs. 4 and 8) nor for protein biosynthesis in vivo, although such a structure may be present inside cells.

Clearly many inactive monomeric ribosomes exist in RNP preparations of rat liver but so do active monomeric ribosomes, for the experiment depicted in Fig. 4 shows that monomeric ribosomes can incorporate amino acids into protein. We have for some years used ribosomes, prepared by a method (Korner, 1961) that yields monomeric and dimeric ribosomes ( 80 and $110 \mathrm{~s})$, which incorporate amino acids into protein to a reasonable extent. They are not quite as active/mg. of RNA as polysomes but certainly are sufficiently active to lend support to our contention that monomeric ribosomes are capable of amino acid incorporation into protein, in contradiction to the findings of Wettstein et al. (1963) and Noll et al. (1963).

We have pointed out in this paper and elsewhere (Jackson et al. 1963) the over-estimation of the number of monomeric ribosomes on a gradient which can occur if a correction for the presence of ferritin is not made. Under-estimation of the ability of a particular type of RNP particle to incorporate amino acids into protein is possible unless the conditions of incubation used are capable of producing optimum amino acid incorporation (Table 1). Care must also be exercised to remove inhibitors from cell sap and to use sufficient of it (Fig. 1). These technical points, together with the differences in methods of preparation of $\mathrm{RNP}$ particles, may account for the difference between the results of Noll et al. (1963) and our own on the question of the ability of monomeric ribosomes to incorporate amino acid into protein. Recently, Staehelin et al. (1963a) have classified monomeric ribosomes into four classes, of which theoretically two are potentially active. Since they could find no activity in the monomeric region, these workers suggest that these classes represent only a small fraction of the total monomeric ribosomes.

Our conclusion that monomeric ribosomes are able to incorporate amino acids into protein is in agreement with the findings of some other workers: Haselkorn, Fried \& Dahlberg (1963) found that virus RNA, attached to single $E$. coli ribosomes, could cause amino acid incorporation; Marcus, Bretthauer, Bock \& Halvorson (1963) showed that the length of synthetic polynucleotide which could stimulate amino acid incorporation was so small in some instances that only a single ribosome could have been attached to it; White et al. (1963) showed that only monomeric ribosomes of ascites-tumour cells could attach themselves to polyuridylic acid, were then active and did not form aggregates. Other workers have produced evidence which shows that aggregates are formed when polyuridylic acid is added to ribosomes (Barondes \& Nirenberg, 1962; Spyrides \& Lipmann, 1962; Gilbert, 1963), but Takanami \& Okamoto (1963) have found that multiple attachment of ribosomes to polyuridylic acid occurs only when the polyuridylic acid/ribosome ratio is small; when large amounts of polyuridylic acid are present it is attached mainly to single ribosomes.

Again in contrast with the findings of Wettstein et al. (1963) we find that reducing the magnesium content of the suspending medium has a considerable effect on polysome structure and size (Fig. 5). The breakdown of polysomes to smaller units on lowering the magnesium concentration cannot be ascribed to ribonuclease degradation of the messenger RNA (Fig. 7 and Table 3). Reversal of the degradation by raising the magnesium concentration, if it occurs at all, is only to a limited extent (Fig. 6). It appears that ribosomes can be plucked from the polysome structure on lowering the concentration of $\mathrm{Mg}^{2+}$ ions.

This conclusion is supported by the prelabelling of polysomes with radioactive amino acids (Fig. 8) 
and with radioactive orotic acid (Fig. 9). In both cases, washing the particles in a medium containing no magnesium resulted in greater specific activity in the remaining polysomes than when washing was carried out with a medium containing magnesium. Plucking ribosomes from the labelled messenger RNA could explain this increased specific activity in orotic acid labelling (Fig. 9) but an extra condition must be introduced to explain the result of Fig. 8. During the labelling period in vivo, some of the ribosomes later found attached to the isolated polysomes had been inactive and more of these unlabelled ribosomes than labelled ones were removed when the polysomes were centrifuged through a medium without magnesium. Loss of more unlabelled than labelled ribosomes explains the higher specific activity at the heavy end of the gradient in the preparation made without magnesium. Henshaw, Bojarski \& Hiatt (1963) have shown that single inactive ribosomes can be detached from ratliver microsomes by lowering the concentration of $\mathrm{Mg}^{2+}$ ion and Cannon, Krug \& Gilbert (1963) have found that inactive ribosomes in bacteria are bound less strongly to the template than are the active ones.

Our picture of the isolated polysome suggests that inactive ribosomal particles may be attached to it. Such a structure may be present in vivo or may have arisen during preparation by the inactivation of some of the ribosomes on the polysome or the non-specific attachment of inactive ribosomes to the polysome (cf. Marks et al. 1962).

The model of polysomes favoured by Wettstein et al. (1963) suggests that the length of messenger RNA increases with increasing ribosome number and that each ribosome is active and can roll to one end of the messenger RNA and then detach from the messenger RNA. This model would result in a linear rise in specific activity with increase in polysome size yet the results of Noll et al. (1963) (Fig. 1) show such a linear rise only to about eight ribosomes and then a plateau of specific activity with larger sizes of polysomes. This plateau cannot be explained without introducing a further constraint into the model: either the incorporating system stops before more than eight ribosomes can roll off the end of the messenger RNA or each of the ribosomes can roll only for a distance which is less than the total length of the messenger RNA. An alternative explanation is that the linear length of the messenger RNA does not increase directly with increase in ribosome number but that non-specific aggregation of polysomes to heavier aggregates can occur. Some observations of our own favour the last-named view.

In the models of the protein-biosynthetic mechanism it was necessary to postulate that the ribosomes must move relative to the messenger RNA.
The experimental evidence produced to support the idea of ribosomes rolling along the messenger RNA (Noll et al. 1963) is that amino acid incorporation is accompanied by the breakdown of polysomes to monomers, the specific activity of which rises with increasing time of incubation. This result is interpreted as ribosomes rolling off the end of messenger RNA when they have completed their protein, but no evidence was presented to counter the possibility that monomers detached themselves from the middle of the messenger RNA. We have noted that preincubation of polysomes in an incubation medium without ATP, where protein synthesis could not occur, resulted in breakdown of poly. somes without incorporation. In other words, breakdown of polysomes is not necessarily dependent on protein synthesis : models other than rolling of ribosomes over messenger RNA must not be ruled out of consideration.

When one tries to visualize the working of the proposed models in a living cell one encounters the difficulty of ribosomes rolling along messenger RNA when the particles are firmly attached to lipoprotein membranes of the endoplasmic reticulum. The obvious suggestion is that messenger RNA slides over the static ribosomes but at least one other possibility is that it is the peptide-forming enzyme(s) which move over the messenger RNA surface attached to the ribosomes.

\section{SUMMARY}

1. Conditions needed to achieve optimum amino acid incorporation into protein in vitro with ratliver ribosomes, polysomes and a preparation of the total ribonucleoprotein particles are defined. Enough cell sap (from which inhibitors had been removed) must be added so that it is not limiting.

2. It was shown that the RNA strand holding ribosomes in the polysome structure had some of the characteristics of messenger RNA since it was rapidly labelled with $\left[{ }^{3} \mathrm{H}\right]$ orotic acid and its synthesis was sensitive to treatment of the rats with actinomycin.

3. It was shown that a polysome structure was not essential for amino acid incorporation into protein and that single ribosomes, suitably attached to messenger RNA, could be active.

4. Polysome aggregates could be degraded to smaller and ultimately mainly to monomeric and dimeric ribosomes by lowering the $\mathrm{Mg}^{2+}$ ion concentration of the suspending medium. This process was not caused by ribonuclease activity but by plucking ribosomes from the polysome structure and was reversible only to a very limited extent.

5. Polysomes, centrifuged through media containing various magnesium concentrations, yielded varying proportions of different sizes of ribonucleo- 
protein particles, yet the ability of the preparations to incorporate amino acids into protein were not greatly different from one another. Polysomes prepared in the presence or absence of magnesium differed but slightly in their ability to incorporate amino acids into protein.

6. Ribonucleoprotein particles from liver of a rat given an injection of radioactive amino acids were analysed by sucrose-gradient centrifugation in the presence or absence of $\mathbf{M g}^{2+}$ ions. The specific activity was higher in the heavy region and the fall of specific activity steeper in the absence of $\mathrm{Mg}^{2+}$ ions.

7. A similar analysis after $\left[{ }^{3} \mathrm{H}\right]$ orotic acid labelling of the messenger RNA again showed a difference of the same type in the slopes of the gradients in the presence or absence of $\mathbf{M g}^{2+}$ ions.

8. One explanation of the results summarized in paragraphs 5, 6 and 7 above is that not each ribosome of the polysome structure is active and that the inactive particles are preferentially removed on decreasing the magnesium concentration.

9. Models of the protein-synthesizing structure proposed by other workers are discussed in the light of our findings.

We are grateful to the Medical Research Council, the British Empire Cancer Campaign and The Royal Society for financial support of various aspects of this work. R.J.J. thanks the D.S.I.R. for a research studentship. Mrs B. Brown and Miss J. Gumbley gave highly skilled assistance in part of the work, and Professor F. G. Young is thanked for encouragement.

\section{REFERENCES}

Arnstein, H. R. V. (1961). Biochem. J. 81, 240.

Barondes, S. H. \& Nirenberg, M. W. (1962). Science, 138 , 813.

Britten, R. J. \& Roberts, R. B. (1960). Science, 131, 32.

Cannon, M., Krug, R. \& Gilbert, W. (1963). J. molec. Biol.7, 360.

Dingman, W. \& Sporn, M. B. (1962). Biochim. biophys. Acta, 61, 164.

Earl, D. C. N. \& Korner, A. (1963). Biochem. J. 89, 15 P.

Elson, D. \& Tal, M. (1959). Biochim. biophys. Acta, 36, 281.

Fleck, A. \& Munro, H. N. (1962). Biochim. biophys. Acta, $55,571$.

Franklin, R. M. (1963). Biochim. biophys. Acta, 72, 555.

Gierer, A. (1963). J. molec. Biol. 6, 148.

Gilbert, W. (1963). J. molec. Biol. 6, 374.

Goodman, H. M. \& Rich, A. (1963). Nature, Lond., 199, 318.
Gray, W. R. \& Hartley, B. S. (1963). Biochem. J. 89, 59 P.

Hall, B. D. \& Doty, P. (1959). J. molec. Biol. 1, 111.

Hamilton, M. G. \& Petermann, M. L. (1959). J. biol. Chem. 234, 1441.

Haselkorn, R., Fried, V. A. \& Dahlberg, J. E. (1963). Proc. nat. Acad. Sci., Wash., 49, 511.

Henshaw, E. C., Bojarski, T. B. \& Hiatt, H. H. (1963). J. molec. Biol. 7, 122.

Hiatt, H. H. (1962). J. molec. Biol. 5, 217.

Jackson, R. J., Munro, A. J. \& Korner, A. (1963). Biochem. J. 89, $11 \mathrm{P}$.

Kirsch, J. F., Siekevitz, P. \& Palade, G. E. (1960). J. biol. Chem. 235, 1419.

Korner, A. (1961). Biochem. J. 81, 168.

Korner, A. \& Munro, A. J. (1963). Biochem. biophys. Res. Commun. 11, 235.

Lowry, O. H., Rosebrough, N. J., Farr, A. L. \& Randall, R. J. (1951). J. biol. Chem. 193, 265.

Mansbridge, J. \& Korner, A. (1963). Biochem. J. 89, 15 P.

Marcus, L., Bretthauer, R. K., Bock, R. M. \& Halvorson, H. O. (1963). Proc. nat. Acad. Sci., Wash., 50, 782.

Marks, P. A., Burka, E. R. \& Schlessinger, D. (1962). Proc. nat. Acad. Sci., Wash., 48, 2163.

Merrits, I. (1963). Biochem. biophys. Res. Commun. 10, 254.

Munro, A. J. \& Korner, A. (1962). Biochem. J. 85, 37 P.

Noll, H., Staehelin, T. \& Wettstein, F. O. (1963). Nature, Lond., 198, 632.

Palade, G. E. \& Siekevitz, P. (1956). J. biophys. biochem. Cytol. 2, 171.

Penman, S., Scherrer, K., Becker, Y. \& Darnell, J. E (1963). Proc. nat. Acad. Sci., Wash., 49, 654.

Sachs, H. (1958). J. biol. Chem. 233, 650.

Scott, J. F., Fraccastoro, A. P. \& Taft, E. B. (1956). J. Histochem. Cytochem. 4, 1.

Spyrides, G. \& Lipmann, F. (1962). Proc. nat. Acad. Sci., Wash., 48, 1977.

Staehelin, T., Brinton, C. C., Wettstein, F. O. \& Noll, H. (1963a). Nature, Lond., 199, 865.

Staehelin, T., Wettstein, F. O. \& Noll, H. (1963b). Science, $140,180$.

Takanami, M. \& Okamoto, T. (1963). J. molec. Biol. 7, 323.

Tissières, A., Schlessinger, D. \& Gros, F. (1960). Proc. nat. Acad. Sci., Wash., 46, 1450.

Warner, J. R., Knopf, P. M. \& Rich, A. (1963). Proc. nat. Acad. Sci., Wash., 49, 122.

Warner, J. R., Rich, A. \& Hall, C. E. (1962). Science, 138, 1399.

Wettstein, F. O., Staehelin, T. \& Noll, H. (1963). Nature, Lond., 197, 430.

White, A. M., Pedersen, S. \& Hultin, T. (1963). Biochem. J. 89, 12 P.

Williamson, R. \& Mathias, A. P. (1963). Biochem. J. 89, 13 P.

Williamson, R., Mathias, A. P., Huxley, H. E. \& Page, S. (1963). Biochem. J. 89, 13 P. 